\title{
Salvia miltiorrhiza extract inhibits TPA-induced MMP-9 expression and invasion through the MAPK/AP-1 signaling pathway in human breast cancer MCF-7 cells
}

\author{
JEONG-MI KIM ${ }^{1 *}$, EUN-MI NOH ${ }^{1 *}$, HYUN-KYUNG SONG ${ }^{1}$, MINOK LEE $^{1}$, SOO HO LEE ${ }^{2}$, \\ SUENG HYUK PARK ${ }^{2}$, CHAN-KEUN AHN ${ }^{3}$, GUEM-SAN LEE ${ }^{4}$, EUI-BAEK BYUN ${ }^{5}$, \\ BEOM-SU JANG ${ }^{5}$, KANG-BEOM KWON ${ }^{1,2}$ and YOUNG-RAE LEE ${ }^{1,6-8}$ \\ ${ }^{1}$ Center for Metabolic Function Regulation; Departments of ${ }^{2}$ Korean Physiology, \\ ${ }^{3}$ Otolaryngology and Dermatology, and ${ }^{4}$ Herbology, Wonkwang University School of Korean Medicine, Iksan, \\ North Jeolla 570-749; ${ }^{5}$ Advanced Radiation Technology Institute, Korea Atomic Energy Research Institute, \\ Jeongeup, North Jeolla 580-185; ${ }^{6}$ Department of Oral Biochemistry; ${ }^{7}$ Institute of Biomaterials Implant, School of \\ Dentistry; ${ }^{8}$ Integrated Omics Institute, Wonkwang University, Iksan, North Jeolla 570-749, Republic of Korea
}

Received February 16, 2017; Accepted June 9, 2017

DOI: $10.3892 / \mathrm{ol} .2017 .6638$

\begin{abstract}
Cancer cell invasion is crucial for metastasis. A major factor in the capacity of cancer cell invasion is the activation of matrix metalloproteinase-9 (MMP-9), which degrades the extracellular matrix. Salvia miltiorrhiza has been used as a promotion for blood circulation to remove blood stasis. Numerous previous studies have demonstrated that S. miltiorrhiza extracts (SME) decrease lipid levels and inhibit inflammation. However, the mechanism behind the effect of SME on breast cancer invasion has not been identified. The inhibitory effects of SME on 12-O-tetradecanoylphorbol-13-acetate (TPA)-induced MMP-9 expression were assessed using western blotting, reverse transcription-quantitative polymerase chain reaction and zymography assays. MMP-9 upstream signal proteins, including mitogen-activated protein kinases and activator protein 1 (AP-1) were also investigated. Cell invasion was assessed using a matrigel invasion assay. The present study demonstrated the inhibitory effects of the SME ethanol solution on MMP-9 expression and cell invasion in TPA-treated
\end{abstract}

Correspondence to: Professor Kang-Beom Kwon, Department of Korean Physiology, Wonkwang University School of Korean Medicine, 460 Iksandae-ro, Iksan, North Jeolla 570-749, Republic of Korea

E-mail: desson@wku.ac.kr

Professor Young-Rae Lee, Department of Oral Biochemistry, School of Dentistry, Wonkwang University, 460 Iksandae-ro, Iksan, North Jeolla 570-749, Republic of Korea

E-mail:mindyr@wku.ac.kr

*Contributed equally

Key words: Salvia miltiorrhiza extract, human matrix metalloproteinase-9, invasion, activator protein 1 , breast cancer MCF-7 cell line
MCF-7 breast cancer cells. SME suppressed TPA-induced MMP-9 expression and MCF-7 cell invasion by blocking the transcriptional activation of AP-1. SME may possess therapeutic potential for inhibiting breast cancer cell invasiveness.

\section{Introduction}

Salvia miltiorrhiza roots have traditionally been used for the treatment of gynecological disorders in Chinese medicine (1). S. miltiorrhiza extracts (SME) have been suggested to decrease lipid levels and inhibit inflammation (2-4), and have demonstrated cytotoxic effects on cells derived from various types of human cancer, including the lung, colon and pancreas (5-7). Previously, Tanshinone II-A, extracted from S. miltiorrhiza, inhibited invasion and metastasis of human carcinoma cells $(8,9)$. More notably, certain studies have demonstrated that SME exhibits antitumor effects in breast cancer cells $(10,11)$. However, the inhibitory effect of SME on breast cancer invasion was not known.

Breast cancer is a malignant tumor with the ability to spread beyond the breast tissue. The patients with breast cancer exhibited a high mortality rate (12), primarily caused by metastasis and invasion of cancer cells. Consequently, the primary approach for breast cancer treatment has been the development of effective anti-metastasis and anti-invasion drugs $(13,14)$.

Invasion and metastasis of cancer cells are characterized by the degradation of the extracellular matrix (ECM) by proteases secreted from cancer cells $(15,16)$. A total of 24 types of human matrix metalloproteinases (MMPs) are synthesized and secreted from cells $(17,18)$. Of those, MMP-9 is well known as a key enzyme that regulates breast cancer cell invasion (19). High concentrations of MMP-9 were identified in breast cancer tissue compared with those in normal breast tissue (20). A variety of stimulators such as tissue plasminogen activator (TPA), tumor necrosis factor- $\alpha$ and epidermal growth factor may increase the expression of MMP-9 in cancer cells (21-24). 
Cytokine and TPA-mediated MMP-9 expression is controlled by the transcription factors, nuclear factor- $\kappa \mathrm{B}$ $(\mathrm{NF}-\kappa \mathrm{B})$ and activator protein-1 (AP-1) in cancer cells $(19,25,26)$. AP-1 is the collective name for referring to dimeric transcription factor proteins composed of Jun proto-oncogene, Fos proto-oncogene and the activated transcription factor protein families (27). Dimerized Jun/Fos bind to specific AP-1 sites of DNA, but their functions depend on cell type and activating agent (28-31). NF- $\kappa \mathrm{B}$ forms a complex with its cellular protein inhibitor (inhibitory $\kappa \mathrm{B} \alpha$; I $\kappa \mathrm{B} \alpha$ ) and thereby remains inactive in the cytoplasm (32). When TPA phosphorylates $\mathrm{I} \kappa \mathrm{B}$ this complex dissociates, releasing $\mathrm{NF}-\kappa \mathrm{B}$, which then translocates to the nucleus where it interacts with DNA binding sites on the MMP-9 promoter $(33,34)$. Previously, Hsieh and $\mathrm{Wu}(28)$ suggested that $S$. miltiorrhiza roots have capacity to regulate $\mathrm{NF}-\kappa \mathrm{B}$.

In the present study, it has been hypothesized that SME may exhibit anticancer properties through the inhibition of cell invasion. Therefore, the molecular mechanism by which SME affects the invasiveness of the breast cancer MCF-7 cell line was investigated. SME reduced TPA-induced cell invasion via the mitogen-activated protein kinase (MAPK)/AP-1 signaling pathways, and decreased MMP-9 expression was associated with the extent of the inhibition of breast cancer cell invasion.

\section{Materials and methods}

Cell and reagents. MCF-7 cells were acquired from the American Type Culture Collection (Manassas, VA, USA). Cells were cultured in Dulbecco's modified Eagle medium (Thermo Fisher Scientific, Inc., Waltham, MA, USA) supplemented with $1 \%$ antibiotics $(10,000 \mathrm{U} / \mathrm{ml}$ penicillin, $10,000 \mu \mathrm{g} / \mathrm{ml}$ streptomycin, $25 \mu \mathrm{g} / \mathrm{ml}$ amphotericin B) and $10 \%$ fetal bovine serum (Thermo Fisher Scientific, Inc.) at $37^{\circ} \mathrm{C}$ in an incubator with $5 \% \mathrm{CO}_{2}$ saturation. DAPI, TPA, dimethyl sulfoxide and anti- $\beta$-actin antibody were purchased from Sigma-Aldrich (Merck KGaA, Darmstadt, Germany). Antibodies against MMP-9 (catalog no. 12759), inhibitory $\kappa$ B kinase (IKK) $\alpha$ (catalog no. 2682), IKK $\beta$ (catalog no. 2678), proliferating cell nuclear antigen (PCNA; catalog no. 7907), IкB $\alpha$ (catalog no. 371), transcription factor p65 (catalog no. 372), and horseradish peroxidase (HRP)-conjugated immunoglobulin $\mathrm{G}$ (IgG) (catalog no. 2004, 2005) were obtained from Santa Cruz Biotechnology, Inc. (Dallas, TX, USA). Antibodies against c-Jun N-terminal kinase (JNK; catalog no. 9252), p38 (catalog no. 9212), extracellular signal-regulated kinase (ERK; catalog no. 9102), phosphorylated (p)-JNK (catalog no. 9252), p-p38 (catalog no. 9211), p-ERK (catalog no. 9101), p-c-Jun (catalog no. 9261), p-IкB $\alpha$ (catalog no. 2859) and p-IKK $\alpha / \beta$ (catalog no. 2697) were purchased from Cell Signaling Technology, Inc. (Danvers, MA, USA). Goat anti-rabbit Alexa Fluor 568 [IgG heavy and light chains (H\&L)] (catalog no. A-11036) was obtained from Invitrogen (Thermo Fisher Scientific, Inc.).

Preparation of S. miltiorrhiza extract. Dried roots of S. miltiorrhiza Bunge were purchased from Kwangmyungdang Medicinal Herbs Co., Ltd. (Ulsan, Korea) and authenticated by Professor Guem-San Lee (Department of Herbology, Wonkwang University School of Korean Medicine, Iksan, Korea): A voucher specimen (WKU120302-SM201406A) was deposited at the Department of Herbology, College of Korean Medicine, Wonkwang University (Iksan, Korea). S. miltiorrhiza Radix powder (50 g) was extracted by sonication in $500 \mathrm{ml}$ of $70 \%$ aqueous ethanol for $2 \mathrm{~h}$, and then filtered through paper. This procedure was repeated twice. Liquid from the extracted solution was evaporated under $40 \mathrm{mmHg}$ by rotary evaporator, and the resulting product was freeze-dried. The final extraction yield was $6.54 \%(\mathrm{w} / \mathrm{w})$.

Determination of cell viability. MCF-7 cells were seeded on 96-well plates $\left(1.5 \times 10^{4}\right.$ cells/well $)$ and treated with $1,5,10,25$ and $50 \mu \mathrm{g} / \mathrm{ml} \mathrm{SME}$ for $24 \mathrm{~h}$ at $37^{\circ} \mathrm{C}$. Then, $100 \mu \mathrm{l} \mathrm{EZ-CyTox}$ assay reagent (Daeil Lab Service Co., Ltd., Seoul, Republic of Korea) was added 100 times diluted to the plate wells. Next, the cells were incubated for $30 \mathrm{~min}$ at $37^{\circ} \mathrm{C}$ prior to measuring the absorbance with a $540-\mathrm{nm}$ filter in an ELISA reader (Molecular Devices, LLC, Sunnyvale, CA, USA).

Zymography. To analyze the proteolytic activity of MMP-9, zymography was performed as previously described (35). Areas of gelatinase activity were detected as a white zone in a dark blue field.

Western blot analysis. Total protein extracts were prepared using an ice-cold M-PER Mammalian Protein Extraction Reagent (Pierce; Thermo Fisher Scientific, Inc.) according to the manufacturer's protocol. Proteins were quantified using a BioSpec-nano Micro-volume Spectrophotometer (Shimadzu; Columbia, USA). For each lane, $20 \mu \mathrm{g}$ protein was used. The protein samples were separated using SDS-PAGE (10\% gel) and transferred to Hybond ${ }^{\mathrm{TM}}$ polyvinylidene fluoride membranes. The membranes were blocked with $2 \%$ bovine serum albumin (Sigma-Aldrich; Merck KGaA) or 5\% skim milk for $2 \mathrm{~h}$ at $4^{\circ} \mathrm{C}$. Membranes were then incubated overnight at $4^{\circ} \mathrm{C}$ with primary antibodies. $\beta$-actin (catalog no. A2228) was purchased from Sigma-Aldrich (Merck KGaA). MMP-9 (catalog no. 12759), IKK $\alpha$ (catalog no. 2682), IKK $\beta$ (catalog no. 2678), PCNA (catalog no. 7907), IкB $\alpha$ (catalog no. 371) and p65 (catalog no. 372) were obtained from Santa Cruz Biotechnology, Inc. JNK (catalog no. 9252), p38 (catalog no. 9212), ERK (catalog no. 9102), phosphorylated (p)-JNK (catalog no. 9252), p-p38 (catalog no. 9211), p-ERK (catalog no. 9101), p-c-Jun (catalog no. 9261), p-IкB $\alpha$ (catalog no. 2859) and $\mathrm{p}$-IKK $\alpha / \beta$ (catalog no. 2697) were purchased from Cell Signaling Technology, Inc. All Antibodies used were diluted at 1:2,000. Protein expression levels were measured by Mini HD6 image analyzer using Alliance 1D software (UVItec, Cambridge, UK) with Immobilon ${ }^{\mathrm{TM}}$ Western Chemilumi nescent HRP Substrate (enhanced chemiluminescence) kit (EMD Millipore, Billerica, MA, USA).

Reverse transcription-quantitative polymerase chain reaction $(R T-q P C R)$. RNA isolation from cells was performed using the FastPure $^{\mathrm{TM}}$ RNA kit (Takara Bio, Inc., Otsu, Japan). Complementary DNA was synthesized using a PrimeScript ${ }^{\mathrm{TM}}$ RT Reagent kit (Takara Bio, Inc.). qPCR analysis was performed using the StepOnePlus ${ }^{\mathrm{TM}}$ Real-Time PCR System and SYBR Green (both Applied Biosystems; Thermo Fisher Scientific, Inc.) to determine mRNA levels. The thermocycling conditions were as follows: $50^{\circ} \mathrm{C}$ for $2 \mathrm{~min}$ and $95^{\circ} \mathrm{C}$ for $10 \mathrm{~min}$, 
A

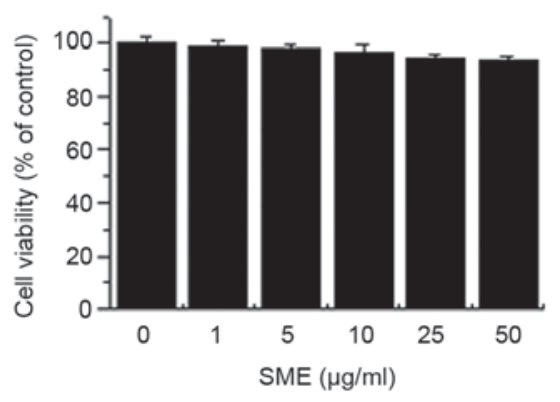

B

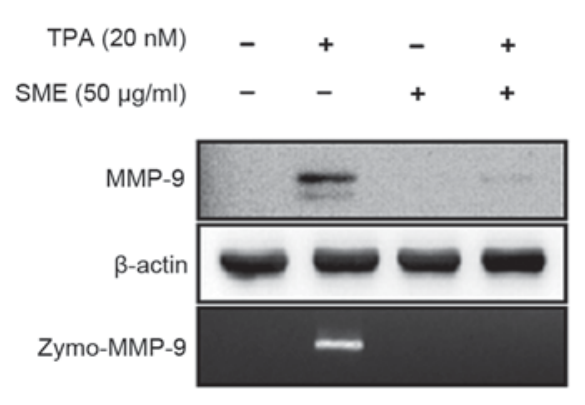

C

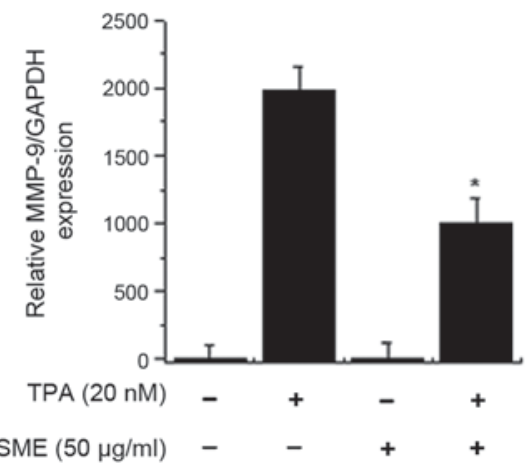

Figure 1. SME inhibits TPA-induced MMP-9 expression in MCF-7 cells. (A) SME was treated at various concentrations (0, $1,5,10,25$ and $50 \mu \mathrm{g} / \mathrm{ml})$ for $24 \mathrm{~h}$. An MTT assay was used to measure cell viability. (B) MCF-7 cells in a monolayer were treated with the indicated SME concentrations in the presence of TPA for $24 \mathrm{~h}$. Cell lysates were analyzed by western blotting with an anti-MMP-9 antibody. The blot was re-probed with an anti- $\beta$-actin antibody to confirm equal loading amounts. Conditioned medium was prepared and used for gelatin zymography. (C) MMP-9 mRNA levels were analyzed by quantitative polymerase chain reaction using GAPDH mRNA as an internal control. Each value represents the mean \pm standard error of the mean of three independent experiments. ${ }^{*} \mathrm{P}<0.05$ vs. TPA only. SME, Salvia miltiorrhiza extract; TPA, 12-O-tetradecanoylphorbol-13-acetate; MMP-9, matrix metalloproteinase-9; Zymo, zymography.

followed by 50 cycles of $95^{\circ} \mathrm{C}$ for $15 \mathrm{sec}$ and $60^{\circ} \mathrm{C}$ for $1 \mathrm{~min}$. The primers used were as follows: MMP-9 (NM 004994) sense, 5'-CCTGGAGACCTGAGAACCAATCT-3' and antisense, 5'-CCACCCGA GTGTAACCATAGC-3'; and GAPDH (NM 002046) sense, 5'-ATGGAAATCCCATCACCATCT T-3' and antisense, 5'-CGCCCCACTTGATTTTGG-3'. The mRNA levels were normalized to the GAPDH housekeeping gene expression levels. The method of quantification was $2^{-\Delta \Delta \mathrm{Cq}}$ method (36).

Automated image acquisition and processing. Cells were fixed with $4 \%$ paraformaldehyde at room temperature for $30 \mathrm{~min}$, and then washed three times with cold PBS. Next, the cells were incubated for $45 \mathrm{~min}$ at room temperature with blocking buffer to prevent nonspecific antibody binding. Then, anti-p-c-Jun (red) antibodies (dilution, 1:1,000) were added and the cells were incubated for $24 \mathrm{~h}$ at $4^{\circ} \mathrm{C}$. Subsequently, the cells were washed three times and then incubated for $1 \mathrm{~h}$ at room temperature with DAPI (blue) and 1:1,000 diluted goat anti-rabbit Alexa Fluor 568 (IgG H\&L) in $0.1 \%$ triton X-100 for nuclear and p-c-Jun staining. Images were captured by an ArrayScan $^{\mathrm{TM}}$ VTI system using Cellomics VHCS: View Software, version 1.6.30 (Cellomics, Inc., Pittsburgh, PA, USA).

Cytoplasmic and nuclear fractionation. MCF-7 cells $\left(2 \times 10^{6}\right)$ were treated with SME and/or TPA for $4 \mathrm{~h}$ at $37^{\circ} \mathrm{C}$. Following this, the cells were centrifuged at $1,500 \mathrm{x} \mathrm{g}$ for $5 \mathrm{~min}$ at $4^{\circ} \mathrm{C}$. Nuclear and cytoplasmic extracts were separated by using NE-PER Nuclear and Cytoplasmic Extraction Reagent (Pierce; Thermo Fisher Scientific, Inc.) according to the manufacturer's protocol.

Invasion and migration assays. The invasion (35) and migration assays (37) were performed as previously described. Cell growth medium $(0.5 \mathrm{ml})$ with cells was added to the upper chamber, and medium with TPA alone or with SME was added to bottom wells.

Statistical analysis. The data were analyzed by one-way analysis of variance and Duncan's multiple range tests using SAS software, version 9.1; (SAS Institute Inc., Cary, NC, USA). $\mathrm{P}<0.05$ was considered to indicate a statistically significant difference.

\section{Results}

Effects of SME on TPA-induced MMP-9 expression and secretion in MCF-7 cells. The treatment of cells with SME did not affect cell viability until concentrations reached $50 \mu \mathrm{g} / \mathrm{ml}$ (Fig. 1A). On that basis, an SME concentration of $50 \mu \mathrm{g} / \mathrm{ml}$ was used for subsequent experiments. In order to investigate the effect of SME on the expression of MMP-9, cells were pretreated with SME for $1 \mathrm{~h}$ and then incubated with TPA for $24 \mathrm{~h}$ at $37^{\circ} \mathrm{C}$. TPA-mediated expression/secretion of MMP-9 was decreased by pre-treatment with SME (Fig. 1B). qPCR analysis revealed that SME significantly reduced the levels of MMP-9 mRNA expression induced by TPA (Fig. 1C).

Effects of SME on the TPA-mediated MAPK signaling pathway. To confirm whether SME is involved in MAPK activation, western blot analysis was performed. Exposure to TPA for 15 or 30 min markedly elevated the phosphorylation levels of $\mathrm{p} 38 / \mathrm{JNK} / \mathrm{ERK}$, and pre-treatment with SME markedly decreased them (Fig. 2).

Effects of SME on TPA-induced NF- $\mathrm{B}$ and AP-1 activation. To confirm this TPA-induced activation of NF- $\kappa \mathrm{B}$ (p65/p50) and AP-1 (c-Jun/c-Fos), immunofluorescence and western blotting were used. TPA induced substantial p-c-Jun expression, whereas pre-treatment with SME blocked it (Fig. 3A and B). Pre-treatment with SME did not affect the translocation of p65 into the nucleus by TPA (Fig. 3B). Additionally, SME did not affect the levels of $\mathrm{p}-\mathrm{IKK} \alpha \beta, \mathrm{p}-\mathrm{I} \kappa \mathrm{B} \alpha$ or I $\mathrm{I} \mathrm{B} \alpha$ induced by TPA (Fig. 3C). These results suggested that SME inhibited TPA-induced MMP-9 expression by blocking AP-1 activation.

Effect of SME on TPA-induced MCF-7 cell invasion/migration in vitro. To demonstrate whether SME inhibits the invasion and migration abilities of MCF-7 cells, in vitro invasion and migration assays were performed. Subsequent to treatment of 


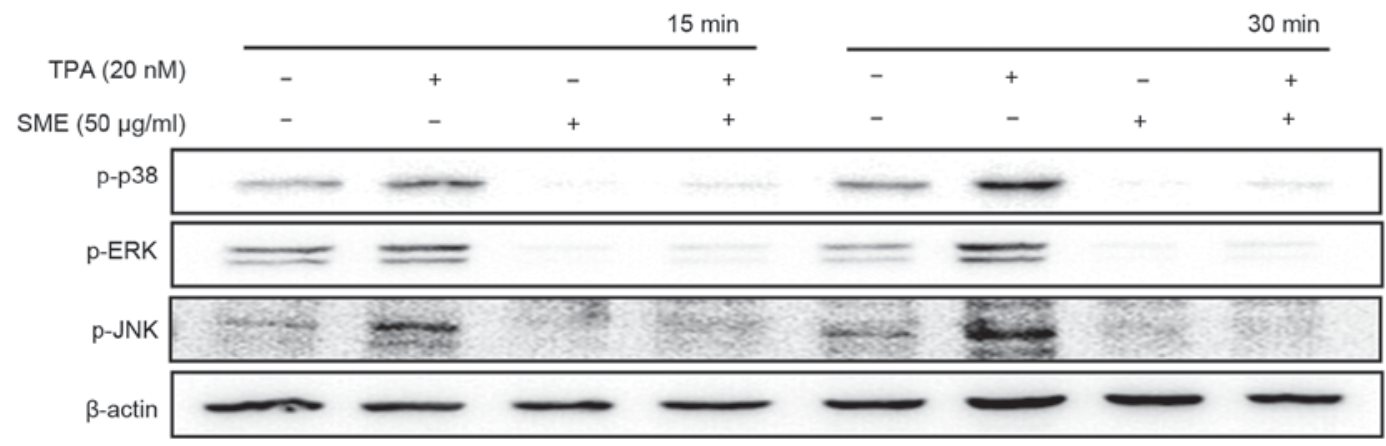

Figure 2. SME inhibits TPA-induced mitogen-activated protein kinase activation in MCF-7 cells. Cells were pretreated with SME for $1 \mathrm{~h}$ and then stimulated with TPA for 15 and $30 \mathrm{~min}$. Western blotting for p-p38, p-ERK and p-JNK was performed as described in the Materials and methods section. SME, Salvia miltiorrhiza extract; TPA, 12-O-tetradecanoylphorbol-13-acetate; p, phosphorylated; ERK, extracellular signal-related kinase; JNK, c-Jun N-terminal kinase.

A

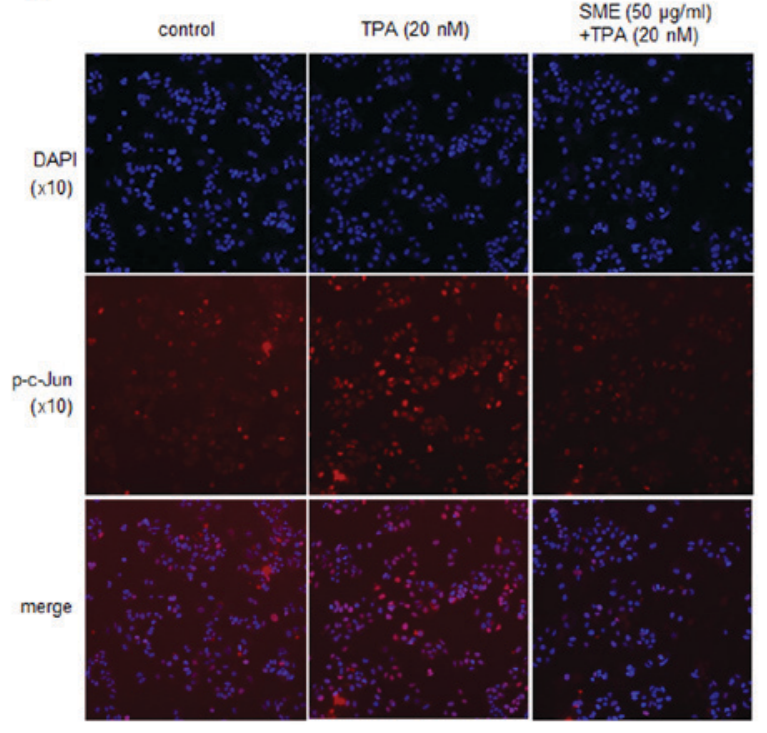

B

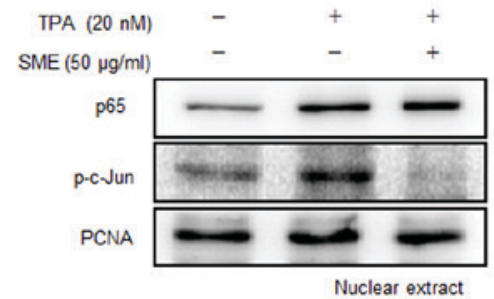

c

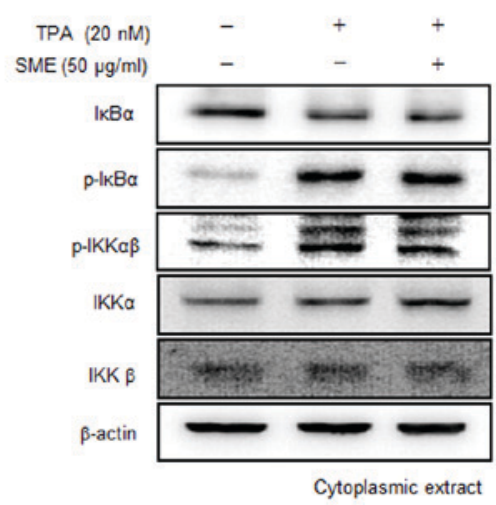

Figure 3. SME suppresses TPA-induced transcriptional activation of MMP-9 by inhibiting AP-1. (A) Cells were pretreated with SME in the presence of TPA. Following $4 \mathrm{~h}$ of incubation, the expression of p-c-Jun in the nucleus was assessed by immunofluorescence analysis (magnification, x10). (B) Cells were pretreated with SME for $1 \mathrm{~h}$ and then exposed to TPA for $4 \mathrm{~h}$. Western blotting was performed to determine the nuclear levels of p65 and activator protein 1 (p-c-Jun) subunits. PCNA was used as loading control. (C) Cells were pretreated with SME for $1 \mathrm{~h}$ and then stimulated with TPA for $4 \mathrm{~h}$.

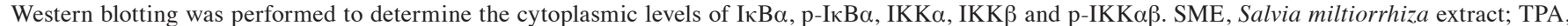
12-O-tetradecanoylphorbol-13-acetate; p, phosphorylated; PCNA, proliferating cell nuclear antigen; IKK, inhibitory к B kinase; IкB $\alpha$, inhibitory к B $\alpha$; p65, nuclear factor- $\kappa \mathrm{B}$ p 65 subunit.
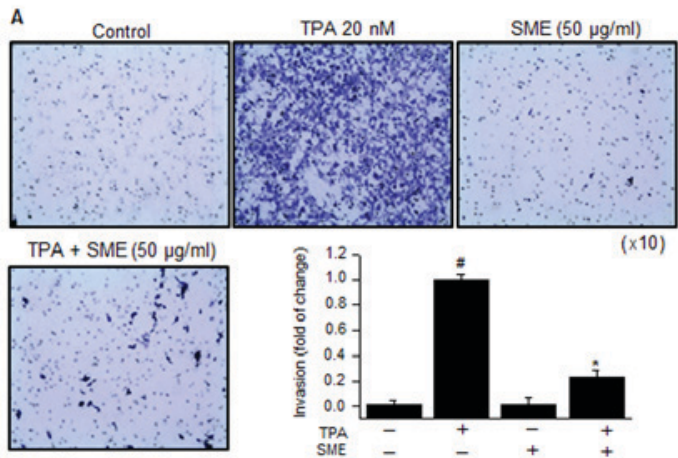
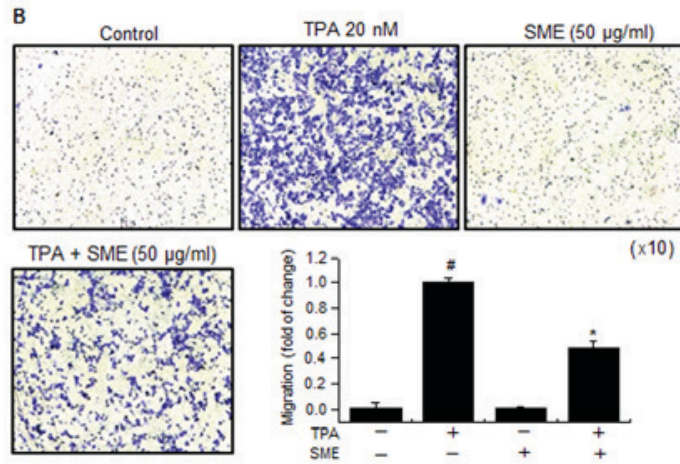

Figure 4. SME inhibits TPA-induced invasion and migration in MCF-7 cells. Change in (A) invasion and (B) migration in MCF-7 cells (magnification, x10). Each value represents the mean \pm standard error of the mean of three independent experiments. ${ }^{"} \mathrm{P}<0.05$ vs. control, $\mathrm{P}<0.05$ vs. TPA only. SME, Salvia miltiorrhiza extract; TPA, 12-O-tetradecanoylphorbol-13-acetate. 
the cells with TPA, the levels of cell invasion and migration were significantly increased. However, the invasion and migration abilities of cells treated with $50 \mu \mathrm{g} / \mathrm{ml} \mathrm{SME}$ and TPA was considerably lower compared with that of cells treated with TPA (Fig. 4).

\section{Discussion}

In the present study, it was revealed that SME blocked TPA-induced cell invasion and MMP-9 expression through inhibition of the MAPK/AP-1 signaling pathway. Concurrently, SME did not affect NF- $\kappa B$ signaling. These results suggest that SME blocks cell invasion by suppressing MMP-9 expression, mediated by the activity of the MAPK/AP-1 signaling pathway, in MCF-7 breast cancer cells.

The ECM provides biochemical and physical barriers to the proliferation and spread of cancer cells, and cancer cell invasion requires its degradation $(38,39)$. Basement membranes consist of various proteins such as collagen, gelatin and other ECM components that are degraded by MMPs. The production of MMPs is tightly controlled by non-specific protease inhibitors or tissue-specific MMP inhibitors (40-43). When this regulation becomes impaired, MMP expression in cancer cells increases abnormally in response to various factors (21-24). In previous studies, this expression was increased by growth factors, inflammatory cytokines, phorbol esters and different signaling pathways in breast cancer cells (44-46). MMP-9 decomposes gelatin and accelerates breast cancer cell invasion (47). Therefore, regulation of MMP-9 expression may be important in treatment strategies for tumor metastasis. Songyou Yin, an herbal compound including S. miltiorrhiza, inhibits tumor invasion via the downregulation of MMPs in hepatocellular carcinoma (48). A previous study reported that SME extracts inhibit the proliferation of MCF-7 cells at a concentration of $5 \mu \mathrm{g} / \mathrm{ml}(49)$. However, the present study confirmed that the inhibitory effect of SME on cell invasion at a concentration of $50 \mu \mathrm{g} / \mathrm{ml}$ does not affect the toxicity of MCF-7 cells. The difference in the concentration of SME for cytotoxicity is considered to be caused by the change of the components depending on the difference of purification processes. The present study suggested that SME inhibited TPA-induced expression of MMP-9 in MCF-7 breast cancer cells (Fig. 1). These results demonstrated that SME has the ability to regulate MMPs.

It has been indicated in several previous studies that the active component of S. miltiorrhiza modulates the MAPK families, including ERK, JNK and p38 kinase. MAPK is involved in cell invasion and protease secretion processes $(50,51)$. In MCF-7 breast cancer cells, the MAPK signaling pathway is activated by protein phosphorylation, which in turn is modulated by TPA $(22,52)$. Previous studies have implicated MAPK in cancer metastasis $(19,21,45)$. In the present study, SME suppressed the TPA-induced phosphorylation of ERK, JNK and p38 in MCF-7 breast cancer cells (Fig. 2).

MAPK families serve an important role in the activation of AP-1. ERK enhances AP-1 activation through c-Fos, whereas JNK leads to the phosphorylation of c-Jun (53). The overexpression of c-Jun enhances MMP-9 expression and in vitro chemo-invasion (54). In the present study, SME blocked TPA-induced c-Jun phosphorylation (Fig. 3). NF- $\kappa$ B is a transcription factor that serves a pivotal role in inducing the expression of MMP-9 $(47,55)$. In the present study, treatment with SME did not inhibit TPA-induced phosphorylation of

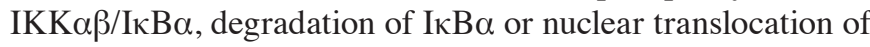
p65NF- $\kappa B$. These data suggest that SME specifically inhibits the MAPK/AP-1 signaling pathway in TPA-induced MCF-7 breast cancer cells. Previously, Tanshinone II-A demonstrated an inhibitory effect on the invasion and metastasis of human carcinoma cells $(8,9)$. However, the mechanism for that effect was not known in breast cancer. Furthermore, Tanshinone II-A is an alcohol extract of the root of the traditional Chinese medicinal plant $S$. miltiorrhiza Bunge. These results indicate that $S$. miltiorrhiza may regulate the invasion abilities of breast cancer. Therefore, the present study assessed the effect of SME on TPA-stimulated cell metastasis in MCF-7 breast cancer cells, and the results indicated that SME inhibited cell invasion (Fig. 4). These findings demonstrated that SME attenuated TPA-induced MMP-9 expression and invasion in MCF-7 breast cancer cells by inhibiting MAPK/AP-1 activation, and revealed the potential use of SME as a traditional therapeutic agent in inhibiting breast cancer metastasis.

\section{Acknowledgements}

The present study was supported by a grant from the National Research Foundation of Korea (NRF) funded by the Nuclear Research \& Development Program of the National Research Foundation (grant no. NRF-2012M2A2A6011335) and by the Korean government (the Ministry of Education, Science Technology); grant no. 2011-0030130), Republic of Korea.

\section{References}

1. Yan X (ed): Dan Shen (Salvia miltiorrhiza) in Medicine. Vol 1. Springer, The Netherlands, 2016.

2. Park CH, Kim DH, Park MH, Kim MK, Kim ND, Kim CM, Tanaka T, Yokozawa T, Chung HY and Moon HR: Chinese prescription Kangen-karyu and Salviae Miltiorrhizae Radix improve age-related oxidative stress and inflammatory response through the PI3K/Akt or MAPK pathways. Am J Chin Med 42: 987-1005, 2014.

3. Xiping Z, Yan P, Xinmei H, Guanghua F, Meili M, Jie N and Fangjie Z: Effects of dexamethasone and Salvia miltiorrhizae on the small intestine and immune organs of rats with severe acute pancreatitis. Inflammation 33: 259-266, 2010.

4. Gu J, Li JC, Tan R, Fan LN and Zhang X: Effects of combination of Puerariae lobatae radix and Salviae miltiorrhizae radix et rhizoma on lipid metabolism in atherosclerotic quails. Zhongguo Zhong Yao Za Zhi 38: 3939-3942, 2013 (In Chinese).

5. Wu CF, Bohnert S, Thines E and Efferth T: Cytotoxicity of Salvia miltiorrhiza against multidrug-resistant cancer cells. Am J Chin Med 44: 871-894, 2016.

6. Ge Y, Yang B, Chen Z and Cheng R: Cryptotanshinone suppresses the proliferation and induces the apoptosis of pancreatic cancer cells via the STAT3 signaling pathway. Mol Med Rep 12: 7782-7788, 2015.

7. Gao H, Sun W, Zhao W, Hao W, Leung CH, Lu J and Chen X: Total tanshinones-induced apoptosis and autophagy via reactive oxygen species in lung cancer 95D Cells. Am J Chin Med 43: $1265-1279,2015$.

8. Yuxian X, Feng T, Ren L and Zhengcai L: Tanshinone II-A inhibits invasion and metastasis of human hepatocellular carcinoma cells in vitro and in vivo. Tumori 95: 789-795, 2009.

9. Shan YF, Shen X, Xie YK, Chen JC, Shi HQ, Yu ZP, Song QT, Zhou MT and Zhang QY: Inhibitory effects of tanshinone II-A on invasion and metastasis of human colon carcinoma cells. Acta Pharmacol Sin 30: 1537-1542, 2009. 
10. Nizamutdinova IT, Lee GW, Lee JS, Cho MK, Son KH, Jeon SJ, Kang SS, Kim YS, Lee JH, Seo HG, et al: Tanshinone I suppresses growth and invasion of human breast cancer cells, MDA-MB-231, through regulation of adhesion molecules. Carcinogenesis 29: 1885-1892, 2008.

11. Nizamutdinova IT, Lee GW, Son KH, Jeon SJ, Kang SS, Kim YS, Lee JH, Seo HG, Chang KC and Kim HJ: Tanshinone I effectively induces apoptosis in estrogen receptor-positive (MCF-7) and estrogen receptor-negative (MDA-MB-231) breast cancer cells. Int J Oncol 33: 485-491, 2008.

12. Redig AJ and McAllister SS: Breast cancer as a systemic disease: A view of metastasis. J Intern Med 274: 113-126, 2013.

13. Siegel R, Ma J, Zou Z and Jemal A: Cancer statistics, 2014. CA Cancer J Clin 64: 9-29, 2014

14. Leber MF and Efferth T: Molecular principles of cancer invasion and metastasis (Review). Int J Oncol 34: 881-895, 2009.

15. Chambers AF and Matrisian LM: Changing views of the role of matrix metalloproteinases in metastasis. J Natl Cancer Inst 89: 1260-1270, 1997.

16. Woodhouse EC, Chuaqui RF and Liotta LA: General mechanisms of metastasis. Cancer 80 (8 Suppl) S1529-S1537, 1997.

17. Yan C and Boyd DD: Regulation of matrix metalloproteinase gene expression. J Cell Physiol 211: 19-26, 2007.

18. Overall CM and Dean RA: Degradomics: Systems biology of the protease web. Pleiotropic roles of MMPs in cancer. Cancer Metastasis Rev 25: 69-75, 2006.

19. Hong S, Park KK, Magae J, Ando K, Lee TS, Kwon TK, Kwak JY, Kim CH and Chang YC: Ascochlorin inhibits matrix metalloproteinase- 9 expression by suppressing activator protein-1-mediated gene expression through the ERK1/2 signaling pathway: Inhibitory effects of ascochlorin on the invasion of renal carcinoma cells. J Biol Chem 280: 25202-25209, 2005.

20. Roy R, Yang J and Moses MA: Matrix metalloproteinases as novel biomarkers and potential therapeutic targets in human cancer. J Clin Oncol 27: 5287-5297, 2009.

21. Liu JF, Crépin M, Liu JM, Barritault D and Ledoux D: FGF-2 and TPA induce matrix metalloproteinase-9 secretion in MCF-7 cells through PKC activation of the Ras/ERK pathway. Biochem Biophys Res Commun 293: 1174-1182, 2002.

22. Przybylowska K, Kluczna A, Zadrozny M, Krawczyk T, Kulig A, Rykala J, Kolacinska A, Morawiec Z, Drzewoski J and Blasiak J: Polymorphisms of the promoter regions of matrix metalloproteinases genes MMP-1 and MMP-9 in breast cancer. Breast Cancer Res Treat 95: 65-72, 2006.

23. Kim S, Choi JH, Kim JB, Nam SJ, Yang JH, Kim JH and Lee JE: Berberine suppresses TNF-alpha-induced MMP-9 and cell invasion through inhibition of AP-1 activity in MDA-MB-231 human breast cancer cells. Molecules 13: 2975-2985, 2008.

24. Kim S, Choi JH, Lim HI, Lee SK, Kim WW, Cho S, Kim JS, Kim JH, Choe JH, Nam SJ, et al: EGF-induced MMP-9 expression is mediated by the JAK3/ERK pathway, but not by the JAK3/STAT-3 pathway in a SKBR3 breast cancer cell line. Cell Signal 21: 892-898, 2009.

25. Chung TW, Moon SK, Chang YC, Ko JH, Lee YC, Cho G, Kim SH, Kim JG and Kim CH: Novel and therapeutic effect of caffeic acid and caffeic acid phenyl ester on hepatocarcinoma cells: Complete regression of hepatoma growth and metastasis by dual mechanism. FASEB J 18: 1670-1681, 2004.

26. Noh EM, Chung EY, Youn HJ, Jung SH, Hur H, Lee YR and Kim JS: Cis-guggulsterone inhibits the IKK/NF-kappaB pathway, whereas trans-guggulsterone inhibits MAPK/AP-1 in MCF-7 breast cancer cells: Guggulsterone regulates MMP-9 expression in an isomer-specific manner. Int J Mol Med 31: 393-399, 2013

27. Hess J, Angel P and Schorpp-Kistner M: AP-1 subunits: Quarrel and harmony among siblings. J Cell Sci 117: 5965-5973, 2004.

28. Lin CW, Hou WC, Shen SC, Juan SH, Ko CH, Wang LM and Chen YC: Quercetin inhibition of tumor invasion via suppressing PKC delta/ERK/AP-1-dependent matrix metalloproteinase- 9 activation in breast carcinoma cells. Carcinogenesis 29: 1807-1815, 2008

29. Lee SO, Jeong YJ, Kim M, Kim CH and Lee IS: Suppression of PMA-induced tumor cell invasion by capillarisin via the inhibition of NF-kappaB-dependent MMP-9 expression. Biochem Biophys Res Commun 366: 1019-1024, 2008.

30. Oh JH, Chung AS, Steinbrenner H, Sies H and Brenneisen P: Thioredoxin secreted upon ultraviolet A irradiation modulates activities of matrix metalloproteinase- 2 and tissue inhibitor of metalloproteinase-2 in human dermal fibroblasts. Arch Biochem Biophys 423: 218-226, 2004.
31. Himelstein BP, Lee EJ, Sato H, Seiki M and Muschel RJ: Tumor cell contact mediated transcriptional activation of the fibroblast matrix metalloproteinase-9 gene: Involvement of multiple transcription factors including Ets and an alternating purine-pyrimidine repeat. Clin Exp Metastasis 16: 169-177, 1998.

32. Jacobs MD and Harrison SC: Structure of an IkappaBalpha/NF-kappaB complex. Cell 95: 749-758, 1998.

33. Kim HR, Kim JM, Kim MS, Hwang JK, Park YJ, Yang SH, Kim HJ, Ryu DG, Lee DS, Oh H, et al: Saussurea lappa extract suppresses TPA-induced cell invasion via inhibition of NF-kappaB-dependent MMP-9 expression in MCF-7 breast cancer cells. BMC Complement Altern Med 14: 170, 2014.

34. Lee YR, Noh EM, Oh HJ, Hur H, Kim JM, Han JH, Hwang JK, Park BH, Park JW, Youn HJ, et al: Dihydroavenanthramide D inhibits human breast cancer cell invasion through suppression of MMP-9 expression. Biochem Biophys Res Commun 405: 552-557, 2011.

35. Kim JM, Noh EM, Kim HR, Kim MS, Song HK, Lee M, Yang SH, Lee GS, Moon HC, Kwon KB and Lee YR: Suppression of TPA-induced cancer cell invasion by peucedanum japonicum thunb. Extract through the inhibition of PKC $\alpha / \mathrm{NF}-\kappa \mathrm{B}-$ dependent MMP-9 expression in MCF-7 cells. Int J Mol Med 37: 108-114, 2016.

36. Livak KL and Schmittgen TD: Analysis of relative gene expression data using real-time quantitative PCR and the 2(-Delta Delta $\mathrm{C}(\mathrm{T})$ ) method. Methods 25: 402-408, 2001.

37. Noh EM, Lee YR, Hong OY, Jung SH, Youn HJ and Kim JS: Aurora kinases are essential for PKC-induced invasion and matrix metalloproteinase-9 expression in MCF-7 breast cancer cells. Oncol Rep 34: 803-810, 2015.

38. Woessner JF Jr: Matrix metalloproteinases and their inhibitors in connective tissue remodeling. FASEB J 5: 2145-2154, 1991.

39. Zwiefel $\mathrm{K}$ and Janni W: Current standards in the treatment of breast cancer. Med Monatsschr Pharm 34: 280-288; quiz 289-290, 2011 (In German).

40. Deryugina EI and Quigley JP: Matrix metalloproteinases and tumor metastasis. Cancer Metastasis Rev 25: 9-34, 2006.

41. Köhrmann A, Kammerer U, Kapp M, Dietl J and Anacker J: Expression of matrix metalloproteinases (MMPs) in primary human breast cancer and breast cancer cell lines: New findings and review of the literature. BMC Cancer 9: 188, 2009.

42. Lombard C, Saulnier J and Wallach J: Assays of matrix metalloproteinases (MMPs) activities: A review. Biochimie 87: 265-272, 2005.

43. Duffy MJ and McCarthy K: Matrix metalloproteinases in cancer: Prognostic markers and targets for therapy (Review). Int J Oncol 12: 1343-1348, 1998

44. Mignatti P and Rifkin DB: Biology and biochemistry of proteinases in tumor invasion. Physiol Rev 73: 161-195, 1993.

45. Cho HJ, Kang JH, Kwak JY, Lee TS, Lee IS, Park NG, Nakajima H, Magae J and Chang YC: Ascofuranone suppresses PMA-mediated matrix metalloproteinase-9 gene activation through the Ras/Raf/MEK/ERK- and Ap1-dependent mechanisms. Carcinogenesis 28: 1104-1110, 2007.

46. Mo N, Li ZQ, Li J and Cao YD: Curcumin inhibits TGF- $\beta 1$-induced MMP-9 and invasion through ERK and Smad signaling in breast cancer MDA- MB-231 cells. Asian Pac J Cancer Prev 13: 5709-5714, 2012.

47. Lungu G, Covaleda L, Mendes O, Martini-Stoica H and Stoica G: FGF-1-induced matrix metalloproteinase-9 expression in breast cancer cells is mediated by increased activities of NF-kappaB and activating protein-1. Mol Carcinog 47: 424-435, 2008.

48. Huang XY, Wang L, Huang ZL, Zheng Q, Li QS and Tang ZY: Herbal extract 'Songyou Yin' inhibits tumor growth and prolongs survival in nude mice bearing human hepatocellular carcinoma xenograft with high metastatic potential. J Cancer Res Clin Oncol 135: 1245-1255, 2009.

49. Yang W, Ju JH, Jeon MJ, Han X and Shin I: Danshen (Salvia miltiorrhiza) extract inhibits proliferation of breast cancer cells via modulation of Akt activity and p27 level. Phytother Res 24: 198-204, 2010.

50. Cobb MH and Goldsmith EJ: How MAP kinases are regulated. J Biol Chem 270: 14843-14846, 1995.

51. Seger R, Biener Y, Feinstein R, Hanoch T, Gazit A and Zick Y: Differential activation of mitogen-activated protein kinase and S6 kinase signaling pathways by 12-O-tetradecanoylphorbol-13-acetate (TPA) and insulin. Evidence for involvement of a TPA-stimulated protein-tyrosine kinase. J Biol Chem 270: 28325-28330, 1995 . 
52. Jemal A, Murray T, Ward E, Samuels A, Tiwari RC, Ghafoor A, Feuer EJ and Thun MJ: Cancer statistics, 2005. CA Cancer J Clin 55: 10-30, 2005.

53. Yao J, Xiong S, Klos K, Nguyen N, Grijalva R, Li P and Yu D: Multiple signaling pathways involved in activation of matrix metalloproteinase-9 (MMP-9) by heregulin-beta1 in human breast cancer cells. Oncogene 20: 8066-8074, 2001.

54. Smith LM, Wise SC, Hendricks DT, Sabichi AL, Bos T, Reddy P, Brown PH and Birrer MJ: cJun overexpression in MCF-7 breast cancer cells produces a tumorigenic, invasive and hormone resistant phenotype. Oncogene 18: 6063-6070, 1999.
55. Eberhardt W, Huwiler A, Beck KF, Walpen S and Pfeilschifter J: Amplification of IL-1 beta-induced matrix metalloproteinase- 9 expression by superoxide in rat glomerular mesangial cells is mediated by increased activities of NF-kappa B and activating protein-1 and involves activation of the mitogen-activated protein kinase pathways. J Immunol 165: 5788-5797, 2000. 